\title{
The butterfly takes flight
}

\author{
Y. Joseph Woo, MD
}

See related article on pages 1296-300.

In this issue of the Journal of Thoracic and Cardiovascular Surgery, Asai and colleagues ${ }^{1}$ report the midterm follow-up results of a novel mitral valve posterior leaflet repair technique. The Asai butterfly, which spread its wings in $2011,{ }^{2}$ now takes flight.

This clever technique was developed by Asai to facilitate fine-tuning of the proven classic Carpentier quadrangular resection. ${ }^{3}$ Typically used for a $\mathrm{P} 2$ prolapse, but applicable to $\mathrm{P} 1$ and $\mathrm{P} 3$ pathology as well, this technique essentially combines a shallow triangular resection with a sliding leaflet annuloplasty, the residual leaflets of which resemble butterfly wings. This repair eliminates the prolapse while preserving enough leaflet tissue to avoid a monoleaflet repair. The annular portion of the resection ensures that the reapproximated residual leaflet from the triangular resection does not protrude too far anteriorly. This ensures a properly posteriorly positioned coaptation line and thus prevents systolic anterior motion. The shape and extent of the resected portions can be varied and customized to the size and shape of each patient's prolapsed segment.

If the resection and reapproximation prove inadequate, additional leaflet tissue can be resected, or the repair can be easily converted to a standard quadrangular resection with annular plication or extended leaflet sliding used to aid approximation of the residual leaflet edges. The only disadvantage of the butterfly repair is that the multiple angled resection lines are straightforward to visualize on a 2-dimensional paper drawing or photograph but are somewhat more difficult to visualize and execute on floppy 3-dimensional leaflet tissue.

In this follow-up study, Asai and colleagues ${ }^{1}$ compared a group of 50 patients on whom a standard quadrangular resection was performed with a more contemporary group of 76 patients who underwent butterfly resection. Systolic anterior motion occurred in 2 patients in the quadrangular resection group but in no patients in the butterfly group. One patient who underwent quadrangular resection required reoperation for anterior leaflet disease, and one patient who underwent the butterfly procedure required reoperation for posterior suture line dehiscence. The overall results are excellent and comparable between the groups. Asai and colleagues ${ }^{1}$ appear to have transitioned to performing this repair as their primary approach to degenerative mitral valve posterior leaflet disease.

This technique is a versatile tool that mitral surgeons should have in their armamentarium. Coupled with standard resection, ${ }^{3}$ neochordal construction, ${ }^{4}$ chordal transposition, and leaflet remodeling techniques, ${ }^{5,6}$ the Asai butterfly is yet another approach to enhance one's mitral valve repair rate. As the drive for earlier repair on symptom-free patients, ${ }^{7}$ professional society guidelines designating reference center capabilities, and competition from transcatheter mitral valve repair devices all escalate the need for very high mitral valve repair success rates, one more effective, durable technique is warmly welcomed.

\section{References}

1. Asai T, Kinoshita T, Suzuki T, Shiraishi S, Koike M. Early and follow-up results of butterfly resection of prolapsed posterior leaflet in 76 consecutive patients. J Thorac Cardiovasc Surg. 2015;149:1296-300.

2. Asai T, Kinoshita T, Nishimura O, Kambara A, Suzuki T, Matsubayashi K. A novel design of posterior leaflet butterfly resection for mitral valve repair. Innovations (Phila). 2011;6:54-6.

3. Carpentier A. Cardiac valve surgery-the "French Correction." J Thorac Cardiovasc Surg. 1983;86:323-37.

4. Falk V, Seeburger J, Czesla M, Borger MA, Willige J, Kuntze T, et al. How does the use of polytetrafluoroethylene neochordae for posterior mitral valve prolapse (loop technique) compare with leaflet resection? A prospective randomized trial. J Thorac Cardiovasc Surg. 2008;136:1205; discussion 1205-6.

5. Tabata M, Ghanta RK, Shekar PS, Cohn LH. Early and midterm outcomes of folding valvuloplasty without leaflet resection for myxomatous mitral valve disease. Ann Thorac Surg. 2008;86:1388-90.

6. Woo YJ, MacArthur JW Jr. Posterior ventricular anchoring neochordal repair of degenerative mitral regurgitation efficiently remodels and repositions posterior leaflet prolapse. Eur J Cardiothorac Surg. 2013;44:485-9; discussion 489.

7. Enriquez-Sarano M, Avierinos JF, Messika-Zeitoun D, Detaint D, Capps M, Nkomo V, et al. Quantitative determinants of the outcome of asymptomatic mitral regurgitation. N Engl J Med. 2005;352:875-83.

From the Department of Cardiothoracic Surgery, Stanford University, Stanford, Calif.

Disclosures: Author has nothing to disclose with regard to commercial support.

Received for publication Jan 26, 2015; accepted for publication Jan 28, 2015; available ahead of print March 5, 2015.

Address for reprints: Y. Joseph Woo, MD, Department of Cardiothoracic Surgery, Stanford University, Falk Building CV-235, 300 Pasteur Dr, Stanford, CA 94305-5407 (E-mail: joswoo@stanford.edu).

J Thorac Cardiovasc Surg 2015;149:1244

$0022-5223 / \$ 36.00$

Copyright (c) 2015 by The American Association for Thoracic Surgery

http://dx.doi.org/10.1016/j.jtcvs.2015.01.048 